\title{
Pearls \& Oy-sters: Facial nerve marginal mandibular branch lesion
}

A complication of carotid surgery

Kimberley Fleuren, MD, and Julie Staals, MD, PhD

Neurology ${ }^{\circledR}$ 2020;94:e2069-e2071. doi:10.1212/WNL.0000000000009415
Correspondence

Dr. Fleuren

kimberley.fleuren@mumc.nl

\section{Pearls}

- Iatrogenic injury of the marginal mandibular branch of the facial nerve is a rare complication of carotid endarterectomy and causes paresis of the ipsilateral lower lip.

- The weakness may be detected by a full denture-type smile or by opening the mouth wide, showing that a person cannot expose his or her lower teeth on the paretic side.

- Paresis of the marginal mandibular branch has minor to no clinical consequences but can have cosmetic consequences.

\section{Oy-sters}

- A marginal mandibular branch lesion may give the false appearance of a central facial nerve palsy.

- Misinterpretation leads to overtesting and incorrect therapeutic strategy.

\section{Case 1}

A 78-year-old woman underwent a left-sided carotid endarterectomy (CEA) because of significant carotid stenosis of $90 \%$, after having had a minor ischemic stroke in the left hemisphere, from which she recovered completely. Before surgery, there was no facial asymmetry. On day 1 after surgery, the vascular surgeon contacted the neurologist for an urgent consult. The surgeon believed the patient had a left-sided facial paresis with a drooped mouth corner, fearing a new ischemic event in the contralateral, nonoperated right hemisphere. On neurologic examination, the resident in neurology noticed facial asymmetry (figure). The patient could not move her left lower lip; movements of the left upper lip and the other facial muscles were intact. The resident in neurology diagnosed a left-sided peripheral lesion of the marginal mandibular branch and reassured the surgeon and patient there was no stroke, but an iatrogenic complication of the surgery.

\section{Case 2}

A 68-year-old man who had a right hemisphere TIA underwent a right-sided CEA because of a high-grade stenosis of $80 \%$ in the right internal carotid artery. After surgery, the surgeon noticed a left-sided drooped mouth and asked the neurologist whether a perioperative ischemic stroke in the right hemisphere had occurred. The resident in neurology noticed that the patient could not move his right lower lip, which gave the impression that his mouth deviated and drooped to the left (figure). The functions of the other facial muscles were intact. The resident concluded that there was an iatrogenic right-sided marginal mandibular branch paresis. One year later, it had not resolved. 


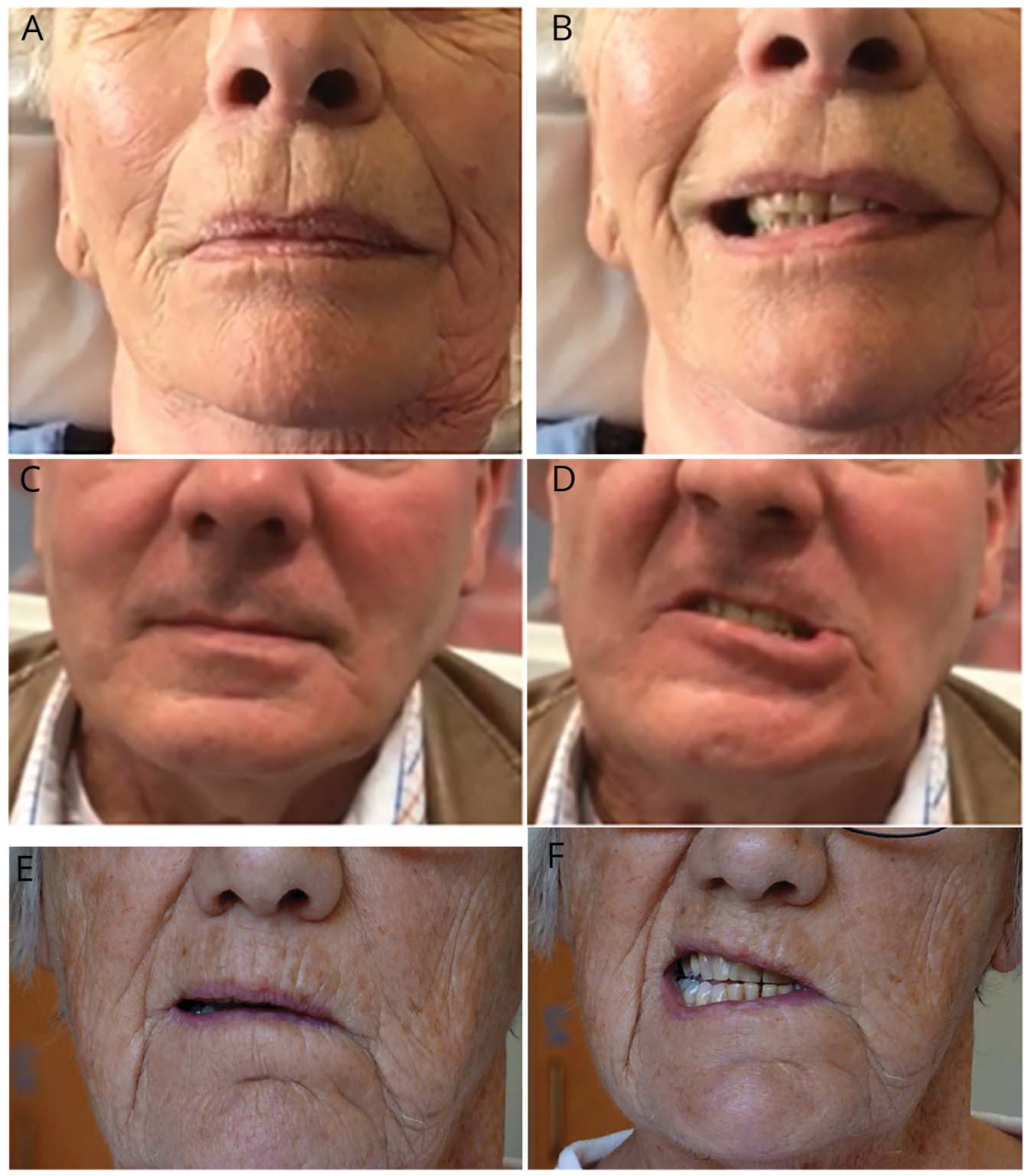

(A, B) Case 1: Left-sided carotid endarterectomy. (A) No asymmetry in neutral nonsmiling position. (B) Full-denture smile shows a left flattened lower lip. (C, D) Case 2: Right-sided carotid endarterectomy. (C) No asymmetry in neutral nonsmiling position. (D) Full-denture smile shows a right flattened lower lip appearing as lip deviation to the left. (E, F) Central facial nerve palsy. (E) Neutral position shows asymmetry with left drooped mouth corner and flattened nasolabial fold. (F) Full-denture smile shows paresis of the left side of the mouth: both upper and lower lip.

\section{Discussion}

The marginal mandibular branch is one of the terminal branches of the mandibular division of the facial nerve. It leaves the anterior-inferior border of the parotid gland, makes a curve down to the submandibular gland, and runs along the angle and inferior border of the mandible. It innervates the muscles of the lower lip, especially the lip depressors. ${ }^{1,2}$ Loss of innervation of the lower lip depressors results in mouth asymmetry during smiling, due to unopposed action of the mouth elevators.

Injury to this branch is often iatrogenic and the result of ipsilateral surgery in the mandibular or parotid regions. ${ }^{1}$ The nerve is particularly prone to damage in the area of the parotid gland, mandibular angle, and superior lateral neck, among others, because of its long course and superficial position. ${ }^{2,3}$ An often unrecognized cause, relevant for the neurologist, is compression by a retractor used during carotid surgery. ${ }^{4}$
A common mistake is to confuse a marginal mandibular branch paresis with a central facial nerve palsy (figure). Patients with a lesion of this nerve branch have symmetrical nasolabial folds and a symmetrical static position of the face, but in a full denture-smile or when opening the mouth wide, one can see that there is a paresis of the muscles of the lower lip. ${ }^{2}$ The patient cannot move the lower lip down or laterally and cannot show his or her lower teeth. At the affected side, the lower lip appears flattened and inwardly rotated. ${ }^{3}$ Sometimes, the lip appears distorted towards the healthy side. It may give the false appearance of a central facial nerve palsy, on either side, because the ipsilateral corner of the mouth does not move (case 1, resembling an ipsilateral central facial palsy indicating a contralateral cerebral event) or because the opposite lower lip moves down (case 2, resembling a contralateral central facial nerve palsy indicating an ipsilateral cerebral event).

Kakisis et al. ${ }^{5}$ found in a large systematic review of 20,860 patients who underwent CEA that fewer than $2 \%$ had cranial 
nerve injury after the procedure, and fewer than 1 in 7 of these injuries was permanent. The vagus nerve was most frequently injured, leading to hoarseness and loss of effective cough, with a pooled injury rate of $3.99 \%$ (95\% confidence interval [CI], 2.56-5.70). The pooled nerve injury rate for the facial nerve was $1.97 \%$ (95\% CI, 1.37-2.66); $11.68 \%$ of these were permanent (0.23\%; 95\% CI, 0.05-0.50). The marginal mandibular branch was reported to have an injury rate of $1.58 \%$ (95\% CI, $0.82-2.54$ ). The percentage of permanent injury was not mentioned. Other possible injuries are injury to the ascending sympathetic fibers causing Horner syndrome, the hypoglossal nerve, the glossopharyngeal nerve, and the spinal accessory nerve. $^{5}$

In contrast, Cunningham et al. ${ }^{6}$ found motor cranial nerve injury in 5.1\% (95\% CI, 4.1-6.2) of patients who underwent CEA; of these, $29 \%$ involved injury of the marginal mandibular branch and more than half of the patients recovered before leaving the hospital. The differences in nerve injury rate between studies probably can be explained by whether there was a routine examination by a neurologist after surgery, time point after surgery, differences in surgery techniques that changed over time, increased awareness, and preventive measures for these nerve injuries. ${ }^{5,6}$

A paresis of the marginal mandibular branch has minor to no functional consequences, although the facial asymmetry can lead to cosmetic embarrassment in patients. ${ }^{5}$ Treatment options consist of temporary relief through botulinum toxin injection into the contralateral depressors and platysma, reconstructive surgery consisting of anterior belly of digastric muscle transfer or extensor digitorum brevis transfer, or depressor labii interoris resection.,
This is in great contrast to the clinical consequences of a central facial palsy due to ischemic stroke. Therefore, it is of great clinical importance to differentiate this relatively benign postsurgery injury from a central facial palsy. ${ }^{6}$

\section{Funding}

No targeted funding reported.

\section{Disclosure}

The authors report no relevant disclosures. Go to Neurology. org/ $\mathrm{N}$ for full disclosures.

Appendix Authors

\begin{tabular}{lll}
\hline Name & Location & Contribution \\
\hline $\begin{array}{l}\text { Kimberley Fleuren, } \\
\text { MD }\end{array}$ & MUMC+ & Draft and revision of manuscript \\
\hline Julie Staals, MD, PhD & MUMC+ & $\begin{array}{l}\text { Revision and supervision of } \\
\text { manuscript }\end{array}$ \\
\hline
\end{tabular}

\section{References}

1. Batra APS, Mahajan A, Gupta K. Marginal mandibular branch of the facial nerve: an anatomical study. Indian J Plast Surg 2010;43:60-64.

2. Kissig B, Kornhuber ME. Neurological picture: clinical test discloses marginalis mandibulae branch lesion of the facial nerve. J Neurol Neurosurg Psychiatry 2006;77:958.

3. Tulley P, Webb A, Chana JS, et al. Paralysis of the marginal mandibular branch of the facial nerve: treatment options. Br J Plast Surg 2000;53:378-385.

4. Sato K, Shimizu S, Oka H, Osawa S, Fujii K. Injury to the marginal mandibular branch of the facial nerve during carotid endarterectomy: a case report. Chirurgia 2014;27:97-99.

5. Kakisis JD, Antonopoulos CN, Mantas G, Moulakakis KG, Sfyroeras G, Geroulakos G. Cranial nerve injury after carotid endarterectomy: incidence, risk factors, and time trends. Eur J Vasc Endovasc Surg 2017;53:320-335.

6. Cunningham EJ, Bond R, Mayberg MR, Warlow CP, Rothwell PM. Risk of persistent cranial nerve injury after carotid endarterectomy. J Neurosurg 2004;101:445-448.

7. Hussain G, Manktelow RT, Tomat LR. Depressor labii inferioris resection: an effective treatment for marginal mandibular nerve paralysis. Br J Plast Surg 2004;57:502-510. 


\section{Neurology}

\section{Pearls \& Oy-sters: Facial nerve marginal mandibular branch lesion: A complication of carotid surgery}

Kimberley Fleuren and Julie Staals

Neurology 2020;94;e2069-e2071 Published Online before print April 21, 2020

DOI 10.1212/WNL.0000000000009415

\section{This information is current as of April 21, 2020}

\section{Updated Information \&} Services

References

Subspecialty Collections

Permissions \& Licensing

Reprints including high resolution figures, can be found at: http://n.neurology.org/content/94/19/e2069.full

This article cites 7 articles, 1 of which you can access for free at: http://n.neurology.org/content/94/19/e2069.full\#ref-list-1

This article, along with others on similar topics, appears in the following collection(s):

\section{All Cerebrovascular disease/Stroke}

http://n.neurology.org/cgi/collection/all_cerebrovascular_disease_strok e

\section{All Education}

http://n.neurology.org/cgi/collection/all_education

Information about reproducing this article in parts (figures,tables) or in its entirety can be found online at:

http://www.neurology.org/about/about_the_journal\#permissions

Information about ordering reprints can be found online:

http://n.neurology.org/subscribers/advertise

Neurology ${ }^{\circledR}$ is the official journal of the American Academy of Neurology. Published continuously since 1951, it is now a weekly with 48 issues per year. Copyright @ 2020 American Academy of Neurology. All rights reserved. Print ISSN: 0028-3878. Online ISSN: 1526-632X.

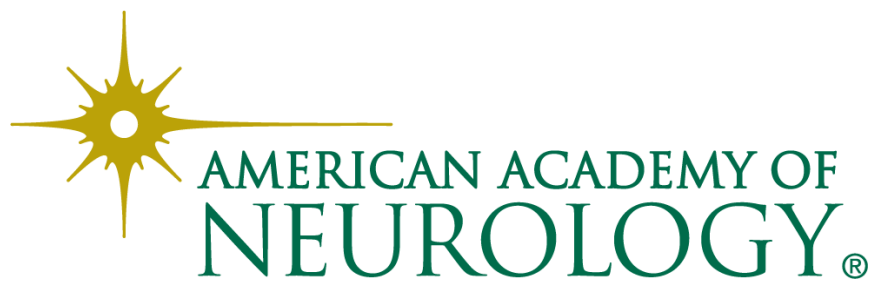

